The case for early administration of parenteral antibiotics to patients with suspected meningococcal disease is now stronger than ever. General practitioners and casualty officers should treat such patients immediately with parenteral (preferably intravenous) benzylpenicillin. (The dose is $1200 \mathrm{mg}$ for adults and children aged 10 and above, $500 \mathrm{mg}$ for children aged 1-9, and $300 \mathrm{mg}$ for children under 1.) Before reconstitution both penicillin and chloramphenicol are stable for at least two years in an emergency bag. Frequent reminders of this simple, cheap measure are needed to reinforce the message.

NORMAN BEGG

Consultant Epidemiologist,

PHLS Communicable Disease Surveillance Centre, London NW9 5EQ
Havens PL, Garland JS, Brook MM, Dewitz BA, Stremski ES, Troshynski TJ. Trends in mortality in children hospitalised with meningococcal infections, 1957 to 1987. Pediatr Infec Dis f 1989;8:8-11.

Jones DM, Kacsmarski EB. Meningococcal infections in England and Wales: 1991. Communicable Disease Report 1992;2:R61-3.

3 Goldacre MJ. Acute bacterial meningitis in childhood: aspects of prehospital care in 587 cases. Arch Dis Child 1977:52:501-3.

4 Department of Health and Social Security. Meningococcal infection: meningitis and septicemia. London: DHSS, 1988. (PL/CMO (88) 2.)

5 Public Health Laboratory Service Meningococcal Infections Working Party. The epidemiology and control of meningococcal disease. Communicable Disease Report 1989;8:3-6.

6 Drugs for the doctor's bag 1989. Drug Ther Bull 1989;27:17-9.
7 Cartwright K, Strang J, Reilly S, White D. Mortality in meningococcal disease. BMf 1992;304:116. 1992;304:116.

8 Ong ELC, Dunbar EM. Antibiotics carried in general practitioners' emergency bags. $B M F^{-}$ 1988;297:901.

9 Cartwright K, Reilly S, White D, Stuart J. Early treatment with parenteral penicillin in meningococcal disease. BMF 1992;305:143-7.

10 Strang JR, Pugh EJ. Meningococcal infections: reducing the case fatality rate by giving penicillin before admission to hospital. BMF 1992;305:141-3.

11 Surtees SJ, Stockton MG, Gietzin TW. Allergy to penicillin: fable or fact? BMJ 1991;302:1051-2. $\frac{\overline{\mathcal{S}}}{\widehat{T}}$

12 Brandtzaeg O, Kierulf P, Gaustad P, Skulberg A, Bruune JN, Halvorsen S, et al. Plasma endotoxin as a predictor of multiple organ failure and death in systemic meningococcal disease. $\mathcal{F}$ Infect Dis $\mathcal{O}$ 1989;159:195-204

\title{
Anhedonia: exclusion from the pleasure dome
}

\section{A useful marker of biological depression}

The concept of anhedonia, or loss of the experience of pleasure, has fallen in and out of psychiatric fashion over the past century. As psychiatrists are now recognising again the importance of symptoms, the concept of anhedonia is proving useful in identifying certain forms of depression-and their ability to respond to treatment.

In 1897 Ribot introduced the term anhedonia and accused psychologists of paying little attention to the study of the experience of pleasure. ${ }^{1}$ Nevertheless, a review of psychiatric textbooks in the late nineteenth century revealed that the loss of the pleasure response was recognised as an early and important symptom of depressive illness..$^{2-4}$ After the turn of the century psychiatric interest in anhedonia faded, and Jaspers's influential text does not mention it except as an aspect of the more severe, pervasive loss of all emotional response. ${ }^{5}$ Attention then focused on depressed mood as the pathognomonic feature of depressive illness. For instance, the International Classification of Diseases, 9 th revision, still in use today, does not mention anhedonia in its definition of the depressive phase of manic-depressive psychosis but defines the disorder in terms of "a widespread depressed mood of gloom and wretchedness with some degree of anxiety."6

In the 1960s interest in anhedonia resurfaced. Meehl considered that low hedonic capacity, or joylessness, was a heritable trait predisposing to the development of schizophrenia and depression. ${ }^{7}$ For most psychiatrists, however, it was Klein's concept of endogenomorphic depression which revived interest in the notion. ${ }^{8}$ In the search for a reliable clinical marker which would distinguish a state responsive to antidepressant drugs from all the other states of misery variously called depression, depressed mood seemed too vague a concept, retardation difficult to assess, and the so called "biological" symptoms of depression such as appetite and sleep disturbance too common in most somatic illness. ${ }^{9}$

In devising a brief self assessment questionnaire to screen for depressive illness in patients suffering from physical illnessand who would respond to antidepressants - we constructed a depression subscale that concentrated on the experience of loss of pleasure. ${ }^{10}$

The loss of the ability to experience pleasure in what was once enjoyed is a fairly distinct experience. The American Diagnostic and Statistical Manual of Mental Disorders recognised this in its 1980 revision, when the concept of anhedonia was promoted to the position of one of the two pathognomonic features of major depressive disorder. Klein's definition: “a $\vec{\omega}$ sharp, unreactive, pervasive impairment of the capacity too experience pleasure, or to respond affectively, to the anticipation of pleasure" was slightly modified to "a loss of interest or pleasure in all or almost all usual activities and pastimes." Moreover, for the subtype of major depression, for which theterm melancholia was resurrected, the anhedonic experience became essential to the definition. Interestingly, a construct of "somatic" depression appears in the third draft for the 10tho revision of the International Classification of Diseases, which moves away from the "pervasive gloom and wretchedness" of: the present version and produces a symptom based definition dominated by anhedonia.

Research in psychiatry has traditionally proceeded on aํำ categorical basis. Attention is now turning to the study of symptoms. ${ }^{11-13}$ Disturbances in neurobiological systems cause. particular symptoms, and successful therapeutics requires clinicians to pay attention to the symptom as well as to the categorical diagnosis. Thus the anhedonic state which so ofteno follows recovery from the florid phase of an acute schizo phrenic illness may well respond to antidepressant drugs. Weo need now to work on defining symptoms better and on devising means of assessing them. For instance, the presento tendency to combine "loss of interest" with "lack of pleasure'N may be misleading. A gardener may retain an interest in the flowers he grows but no longer experience pleasure at their=. sight or their smell. ${ }^{14}$

Consultant Psychiatrist,

Senior Lecturer in Psychiatry,

St James's University Hospital,

Leeds LS9 7TF

1 Ribot T. The psychology of the emotions. 2nd ed. New York: Walter Scott Publishing, 1911. 2 Bucknill JC, Tuke DH. A manual of psychological medicine. London: Churchill, 1874.

3 Clouston TS. Clinical lectures on mental diseases. London: Churchill, 1896.

4 Bevan LW. A textbook of mental diseases. London: Charles Griffin, 1899.

5 Jaspers K. General psychopathology. Manchester: Manchester University Press, 1962 (Hoenig J Hamilton MW, trans)

6 World Health Organisation. Mental disorders: glossary and guide to their classification with the nint revision of the Intemational Classification of Diseases. Geneva: WHO, 1978.

Meehl PE. Schizotaxia, schizotypy, schizophrenia. Am Psychol 1962;17:827-38.

8 Klein DF. Endogenomorphic depression. Arch Gen Psychiatry 1974;31:447-54.

9 Snaith RP. The concepts of mild depression. Brf Psychiatry 1987;150:387-93.

10 Zigmond A, Snaith RP. The hospital anxiety and depression scale. Acta Psychiatr Scand 1983;67:361-70.

1 Van Praag HM. Reconquest of the subjective; against the waning of psychiatric diagnosing. Br f Psychiatry 1992;160:266-71.

12 Costello CG. Research on symptoms versus research on syndromes. Br f Psychiatry 1992;160: 304-8.

13 Altman E, Jobe TH. Phenomenology of psychosis. Current Opinion in Psychiatry 1992;5:33-7. 14 Snaith P. Clinical neurosis, 2nd ed. Oxford: Oxford University Press, 1991. 